\title{
[Review] Religiously motivated terrorism: a systematic review exploring causal pathways
}

\author{
Frances Hankins $^{1}$, Phil McEvoy, Nat Wright ${ }^{1}$ \\ 1 Spectrum Community Health CIC \\ Funding: The author(s) received no specific funding for this work. \\ Potential competing interests: The author(s) declared that no potential competing interests exist.
}

\section{Abstract}

Religiously inspired terrorism is a broad and contested notion. In the literature it includes reference to acts including 'Islamist', 'ultra-Zionist' and 'Christofascist' violence. A systematic review of quantitative, qualitative and mixed-methods studies published between September 2001 and April 2018 highlighted 1275 papers of which twelve research studies met the inclusion criteria.

\section{Critical Findings}

Findings indicate both religious and nationalist motivators for terrorist activities, rooted in a sense of grievance, often fuelled by geopolitical sensitivities. Religious motivators tend to be associated with lower educational attainment, but education has a positive impact upon modifying violent extremist beliefs.

\section{Implications of the Review for Policy, Practice and Research}

Prisons form a ready setting for such educational activity although it should target the individual since group disengagement from terror networks is rare. There are significant methodological limitations to the retrieved evidence which presents a pressing need for further research to improve both conceptual understanding and effective responses to the phenomenon of religiously inspired terrorism.

\section{Scale of the Problem}

Over 170,000 terrorist incidents have been recorded for the period 1970 to 2017 and 18,814 deaths were recorded in 2017 alone ${ }^{[1]}$. Whilst this is a significant number, it represents a 44 per cent reduction from a peak incidence in 2014. Such a trend is largely related to the initial surge and subsequent decline in influence of Islamic State of Iraq and the Levant (ISIL). Whilst there has been a decline in terrorist incidents, it would appear that it is becoming more geographically widespread. 67 countries recorded at least one death from terrorism in 2017, the second highest number of countries since 2002. The increase in the impact of terrorism was greatest in the Middle East and North Africa, followed 
by sub-Saharan Africa. Afghanistan had more deaths from terrorism than any other country in 2017, overtaking Iraq.

Whilst there is no universally agreed definition for such a contested concept of terrorism, the United Nations Office on Drugs and Crime (UNODC) has provided a "partial, customary definition of terrorism." It states that an act of terrorism would share the following three characteristics. Firstly, there is the perpetration of a criminal act (such as murder, kidnapping, hostage-taking, arson, and so on), or threatening such an act. Secondly, there is an intent to either spread fear among the general population (which generally entails the creation of public danger), or directly or indirectly coerce a national or international authority to take some action, or to refrain from taking it. Thirdly, the act involves a transnational element."[2].

In addition to the difficulties in conceptualising what constitutes terrorist activity, the validity of the notion of a causal relationship between religious belief and terrorism appears contested. One commentator, in undertaking an overview of historical cases of Islamic radicalisation in Malaysia between 1945 and 1978 suggested ethnicity, fanaticism and idealism (rather than religiosity) as contributors. The author suggested that such radicalised activity is driven by failed colonial or nationalist projects. The author further suggested that it is ethnic issues, rather than religious motivators, that have the potential to either enhance or moderate Islamist radicalised beliefs. By way of example, the geopolitical conflict in Palestine is cited as a factor that unites Muslims internationally with the potential to radicalise mainstream Islam ${ }^{[3]}$. This opinion is reflected elsewhere in the literature with a view that there is no real, robust evidence of a link between religion and terrorism. Rather an opinion is provided that the radicalisation rhetoric is damaging and is a result of certain political figures blaming conservative Islam for terrorism, in order to further their own agendas ${ }^{[4][5]}$.

However, Hafez ${ }^{[6]}$, in exploring the concept of Islamist-inspired terrorist activity, argues that there is evidence of Jihadists recruiting individuals to help in defending Islam from America and other Western countries. Recruiters portray Jihad as necessary and as self-defence and retaliation against anyone who is willing to co-operate with 'anti-Muslim' enemies. Such Islamist extremists claim to fight for Sharia law to govern all and to destabilise democracy. Such an opinion is supported by commentators from both forensic psychology and faith leaders ${ }^{[7][8][9]}$. They argue that there is both an ancient and modern historical narrative regarding religiously inspired terrorism being inspired by distorted offshoots of all the major world religions and cite examples of ultra-Zionist violence and violent 'Christofascism', in addition to examples of Islamist terrorism. Opinions tend to become polarised into those citing religiously inspired developmental pathways into terrorism and those citing nationalist motivators ${ }^{[10]}$.

The literature pertaining to such pathways into generic terrorist activity highlights the significance of individuals aligning to an ideology, a grievance and influence of peers ${ }^{[11]}$. Therefore, in the context of both contested opinions regarding developmental pathways into religiously inspired terrorism and the increase in Europe in Islamist inspired terrorist activity in recent years, we undertook a review of the literature. Our aim was to ascertain whether there was empirical evidence for religiously motivated terrorism, and if so, what constitutes causal pathways.

\section{Methods}




\section{Objectives}

Following development and peer review of the full study protocol the review was undertaken using accepted systematic review methodology to appraise evidence regarding developmental pathways ${ }^{[12][13][14]}$.

The main research question was: What is the evidence for religiously motivated terrorist activity and causal pathways into such activity?

\section{Eligibility Criteria}

The following constituted inclusion criteria:

- Empirical evidence validating or refuting the concept of religiously motivated terrorism, and if validating, what factors explain causal pathways into such activity.

The following constituted exclusion criteria:

- Papers considering terrorist activity where no reference is made to possible religious motivators

- Papers considering non-violent extremist behaviours.

\section{Study Design}

Quantitative, qualitative or mixed methods studies published in English language. Opinion pieces, case studies/series and descriptive studies were excluded.

\section{Data sources}

The following databases were searched from September 2001 to April 2018:Medline, Embase, CINAHL, PsycINFO, Scopus, Science Direct and Criminal Justice Abstracts. These databases cover health, social science and criminology evidence bases. Manual searches were undertaken of the following journals: British Medical Journal (BMJ), New England Journal of Medicine, The Lancet Global Health, American Journal of Public Health Research, International Journal of Public Health, Trauma, Violence and Abuse, Terrorism and Political Violence, Behavioural Sciences of Terrorism and Political Aggression and Dynamics of Asymmetric Conflict: Pathways Toward Terrorism and Genocide Unpublished (grey) literature was identified from contacts with experts, hand searches of relevant book chapters, conference and abstracts, reference lists of key papers, and searches of relevant websites.

A full strategy is available from the authors upon request. In brief, the strategy included terms relating to the umbrella terms 'violence', 'radicalisation' and 'religion.'

\section{Study Selection}

Two reviewers independently applied the inclusion and exclusion criteria to all retrieved abstracts. Copies of the full article 
were obtained for those papers which appeared to fulfil the inclusion criteria. If the relevance of a study was unclear from the abstract, then the full text paper was retrieved. Disagreements regarding inclusion were resolved by discussion with a third reviewer.

\section{Data Extraction and Validity Assessment}

Once studies were selected for inclusion in the review, core study information pertaining to author and institution details, publication date, study population, outcomes and findings were extracted using PICO extraction forms ${ }^{[15]}$.

The quality of quantitative papers was assessed using a checklist devised from the UK National Institute for Health and Care Excellence (NICE) guidelines manual[ ${ }^{[16]}$ and the Cochrane Handbook for Systematic Reviews ${ }^{17]}$. The quality of qualitative papers was assessed using a checklist devised from the CASP framework ${ }^{[18]}$. The checklists facilitated the reviewer to make an overall assessment of both internal and external validity. The rating scores were as follows: 1-3, where 1 = good internal validity and 3 = poor internal validity; $\mathrm{a}-\mathrm{c}$ for external validity, where $\mathrm{a}=$ high external validity and $\mathrm{C}=$ low external validity.

\section{Data Synthesis}

Studies which met the inclusion criteria were aggregated by a mixed methods thematic synthesis. Thematic synthesis is an established methodology of coding of text, followed by the development of "descriptive themes" (as presented in the "Results" column in Table 1); and the generation of "analytical themes" (as presented in the subheadings of the "results" section below). Whilst the development of descriptive themes remains 'close' to the primary studies, the synthesis of analytical themes represents a stage of interpretation whereby the reviewers 'go beyond' the primary studies and generate new interpretive constructs, explanations or hypotheses ${ }^{[18]}$.

\section{Table 1.}

\begin{tabular}{|c|c|c|c|}
\hline \multirow[t]{2}{*}{ Authors } & Demographics & Methodology & Outcomes \\
\hline & & $\begin{array}{l}\text { Secondary data analysis of } \\
\text { three databases. 1.The } \\
\text { memorial institute for the } \\
\text { prevention of terrorism } \\
\text { knowledge database } \\
\text { (containing instant } \\
\text { databases of the RAND } \\
\text { terrorism chronology and } \\
\text { the RAND terrorism } \\
\text { incident database: } \\
\text { database compiled by } \\
\text { research staff on } \\
\text { candidate terrorist attacks, } \\
\text { drawing on staff with }\end{array}$ & $\begin{array}{l}\text { Impact of the following } \\
\text { variables upon a } \\
\text { woman's likelihood of } \\
\text { taking part in terrorist } \\
\text { attacks: } 1 \text {.women's } \\
\text { status in political } \\
\text { educational and social } \\
\text { domains (eduational } \\
\text { attainment up to } 25 \\
\text { years of age, women's } \\
\text { economic rights, } \\
\text { women's political }\end{array}$ \\
\hline
\end{tabular}

Results (descriptive themes) 
Dalton \& Asal, 2011 regional expertise, relevant language skills, and in country field work experience). 2. The CIRI Human Rights Data Project to evaluate women's status in political rights, economic rights and social rights in a given country: database compiled from US State Department and Amnesty International reports). 3. International Data on Educational Attainment Project to evaluate average schooling of women 25 years and older: database compiled from census data.

A low confidence coding variable was included to control for possible coding discrepancies. rights, women's social rights). 2.

Characteristics of terrorist organisation (organisational size, organisational age, ideological orientation religious propensity). 3 . Sociopolitical and economic context (energy consumption per capita as a proxy to assess country's level of economic development, polity score to evaluate level of autocracy vs democracy. Regarding ideological orientation just "leftist" and not "far right" orientations were evaluated. educational attainment up to 25 years of age ( $Z$ score $2.17, P<0.05$, coefficient 0.119 , standard error 0.055$)$. 2. Women's social rights $(Z$ score $-2.49, P<0.05$, coefficient -1.76, standard error 0.47). 3 . Organisational size ( $Z$ score $2.21, P<0.05$, coefficient 0.63 , standard error 0.28 ). 4 .

Organisational age ( $Z$ score $3.84, P<0.001$, coefficient 0.05 , standard error 0.01 ). 5 . Energy consumption per capita ( $Z$ score 2.84, $\mathrm{P}<0.005$, coefficient 0.24 , standard error 0.08)

Political Characteristics

1. Alienation from the state: alienation from state structures causing individuals to become prey for violent dogma e.g. anti-muslim conspiracy theories that terrorist arrests were "set-ups", that security services spied on Muslim places of worship, that Muslim suspects could be held without charge with no regard for Habeas Corpus ; however such alienation and distrust for government also felt by young Muslims

2. Foreign policy: a belief that Western geopolitical interests oppress Islam (citing wars in Iraq and Afghanistan as an occupation of Muslim countries). Such a belief unanimous across the sample

3. Experience of Protest: Unlike radicals or young Muslims, terrorists display non-participation in government elections, democracy or the judicial system. They do not engage in peaceful protest. Unlike terrorists, many radicals channel their energy through community work to support the communities they conceptualise as oppressed (for example counselling prisoners in a local prison, travelling to Afghanistan to participate in community work)

\section{Social Characteristics}

1. Education: Compared to radicals, terrorists had slightly lower levels of education, were less likely to be 
1. 61 profiles of convicted 'homegrown' violent extremist terrorists from seven cells (or plots) across Canada or Europe (mean age, gender and ethnic background not stated)

2. 20 individuals who were classed as 'radical' (8 in Europe and 12 in Canada) as defined by expressing dissent from prevailing norms with some social connection or association with the 61 convicted terrorists (mean age, gender and ethnic background not stated)

3. 70 Canadian "young Muslims" (age 18 - 30) (mean age, gender and ethnic background not stated).

4. 75 professionals including security and intelligence experts, senior government officials, community leaders, activists, academics, religious scholars and journalists (mean age, gender and ethnic background not stated).
1. Profiles of the 61 'homegrown' terrorists created not from direct interviews but from data aggregated from interviews with individuals known to such terrorists (i.e. those outlined in section 2 below), newspaper reports and translated court transcripts

2. In-depth interviews of "radicals"

3. Interviews with young Muslims: "most of the interviews" used focus group methodology.

4. Interviews with professionals supported by a review of security services reports, trial information, books, academic publications, media publications e.g. internet blogs and local newspapers).

Data analysed using grounded theory.
Grounded theory to explain the phenomenon of violent radicalisation: characteristics and attitudes, religion and ideology, interactions and relationships, organisations, journey to Jihad. empıoyea, were more IIkely to nave dropped out of education, were less likely to have studied the humanities and more likely to have studied the vocational sciences (for example IT, business or engineering)

2. Discrimination: a perception that the state is determined to exterminate Islam, employment discrimination against Muslims. Such a belief unanimous across the sample.

\section{Personal Characteristics}

1. Identity: dual identity theory of difficulties reconciling Islamic heritage with Western society leading to an extremist ideology providing a clear (albeit negative) identity - a set of norms that reduces uncertainty. Religion also provided a clear set of answers, structures and rules to follow. Such beliefs unanimous across the sample although a number of radicals reporting embracing a devout, but peaceful, Islam during a period of contemplation.

2. Religious Understanding: religiosity of upbringing did not differ significantly between terrorists and radicals; radicals more likely than terrorists to have delved into Islamic history and jurisprudence. Radicals conceptualise terrorists as "warped" and "shallow and baseless" and "not even knowing Islam".

3. Critical Thinking and Learning Radicals expressed a view that terrorists unwilling to engage in critical thinking with a "blind adherence" to literalism and an unwillingness to consider the importance of context (particularly in interpreting the so-called "blood verses" which make reference to religiously motivated violence.

Ideology, Religious Concepts and Beliefs

1.Concepts of takfir(accusing other Muslims of apostasy punishable by death and kafir (a non-believer; plural is kuffar). All groups supported the concept of Kuffar and that some form of segregation can be beneficial. Not stated any differences in application of takfir between groups.

\section{Caliphate and Sharia Law}

Re-installing a caliphate and imposing in Europe were popular concepts amongst both radicals and terrorists, but radicals tended to view it as an impracticable, unrealizable dream.

Introducing Sharia law also seen as 

terrorists. However, the former view it as an aspirational ideal and a system that helped Muslims to live by a moral code rather than oppress.

\section{Scholars and Texts}

1. Terrorists typically draw upon a narrow band of thinkers (four names from historical Islamic scholarship frequently cited). Radicals also familiar with such authors. However they are more able to interpret the historical context in which such scholars were writing e.g. interpret the harsh ideas expressed by authors as a response to the imprisonment and torture they were experiencing at the time of writing.

\section{Jihad in the West and East}

1. Terrorists conceptualised Jihad as a legitimate response to defending Islam and the Ummah (the world's Muslim community) which is under attack. However young Muslims and radicals portrayed "Defensive jihad" as a matter of fairness and selfdefence of one's land, property, religion and family i.e. no different to any other just war, often drawing comparisons with French resistance during the second world war. Radicals do not see Islam as a religion of peace but a religion based upon justified violence and the long tradition of just war theory.

1. Study 1 - 144

"postgraduate" muslim students at a Pakistan, university; mean age 21.5 (range 16-21) gender 80 females and 64 males; ethnic background not stated (implied as Pakistani Asian)

Amjad \& Wood, 2009

\section{Study 2 - 92}

"undergraduate and postgraduate"
Study 1 Repeated measures cross-sectional survey

Study 2: randomised
Study 1: self-report attitude measures using the normative belief measure regarding anti-semitic aggression; followed three days later by completing survey of behavioural intent to join an organisation described as defending Muslim identity and honour by opposing and figthting enemies of Islam such as those of Jewish heritage

Study 2: self-report attitude measures administered at baseline followed by randomisation to one of two groups: brief - -n............
Study $1: 41.7 \%$ refusers, $46.5 \%$ requesters and $11.8 \%$ joiners of the extremist group. Those requesting to join the extremist group more likely than refusers to have normative anti-semitic aggressive beliefs ( $P<0.05$; OR 1.96, 95\% Cl 1.03-3.71). Joiners more likely than refusers to have normative anti-semitic aggressive beliefs ( $P<0.05$; OR 7.09, 95\% Cl 2.61-19.24).

Study 2: $39.1 \%$ refusers, $44.6 \%$ requesters and $16.3 \%$ joiners of the extremist group. Participants in the control group more likely to both request information (OR $5.25,95 \% \mathrm{Cl} 1.87-14.78$ ) and agree to join 
muslim psychology

students at a

Pakistan, university; mean age not stated (range 21-29) gender 53 females and 39 males; ethnic background not stated (implied as Pakistani Asian)
15 prison chaplains from 6 states; 7 gang intelligence officials from 3 states; 3 analysts from the FBI's National Joint Terrorism Task Force; and $\mathbf{3 0}$ prisoners incarcerated for violent crimes at the Franklin Correctional Institution in Florida; Folsom prison and
New Folsom Prison

in California -

including several

members of Jam

‘iyyat UI-Islam Is-

Saheed (JIS - A gang

of Sunni Muslims at

California's New

Folsom Prison). 20

of the prisoners

belonged to gangs

and "most of them

had been in street

gangs before

incarceration." controlied triaı

eaucationaı

intervention delivered

by British Pakistani

psychologist

comprising Muslim-

Jewish relations. or to

a control group

comprising a normal

lecture on cognitive

behavioural therapy

which made no

mention of aggression

or Jewish culture.

Three days later

participants

approached to join the

extremist group

outlined above in Study

"140 hours" of interviews"

reported as part of a

literature review and 2

case studies are presented (only the empirical data

collated from the

interviews is presented in

this review)

Method of data analysis

not stated
Exploration of the process of prisoner radicalization and terrorist recruitment in US correctional institutions and the potential impact of such religious conversions to Buddhism, Hinduism, Islam (both traditional and American versions), Native American, Black Hebrew Israelism, Wicca and Odinism / Asatru. . Specifically:

- Why prisoners convert to Islam and impact upon inmate behaviour

- Relationship between Islam, radicalisation and gangs

- The process of moving from radicalised beliefs to terrorist acts the extremist group (OR 15.41, 95\% Cl 1.87-14.78). No effect of gender upon either requesting information (OR 1.08, 95\% $\mathrm{Cl} 0.40-2.91$ ) or joining (OR $2.10,95 \%$ $\mathrm{Cl}$ 0.54-8.13) . Effectiveness of the intervention mediated by changes in normative beliefs regarding aggression against those of Jewish heritage

(Sobel's $z=2.14, P=0.04)$

Why Prisoners Convert:

Although motivation for some prisoners to convert is personal crisis, or need for protection, the primary reason reported was spiritual searching - i.e. seeking religious meaning to interpret and resolve discontent.

\section{Religious Conversion and Inmate} Behaviour:

Majority who convert to non-JudeoChristian faiths experience self-discipline to help interact in a positive manner. However potential for radicalisation of some through prisoners coming together to create collective identities and carry out directives from their leaders - particularly a phenomenon in maximum-security prisons (e.g. a response to grievances "against the US government for killing innocent civilians in Iraq, and mistreating Muslims at Guantanamo Bay")

\section{Radicalisation/terrorism Process}

Traditional American Islam exposed to a prison inspired Prison Islam fused with prison gang membership and provided members with identity, meaning and a collective grievance against the social forces responsible for their imprisonment

76 cases in which motive was clear (authors state that media tend to omit description of suicide bombers and therefore sample may not be representative). Males more likely than females to have religious rather than nationalist motivation OR 22.50, SE 1.41, P $<0.05$, estimate $3.11 .69 .5 \%$ nationalist 
Sela-

Shayovitz (2007) background -

Palestinian suicide bombers
Impact of age, sex, eduation (elementary, high school, academic),

Preliminary (exploratory) marital status, secondary data analysis of organisational media reports: stratified random sample of 294 articles on suicide bombers published in 3 major daily newspapers in Israel between 2002 and 2005 (Yedi'ot Aharonot, Ma'ariv, Ha'aretz) affiliation (Hamas, Islamic Jihad and Fatah), prior involvement in terrorist acts (first event, non first event) upon motive of Palestinian suicide bombers in conducting terrorist attacks (i.e religious versus nationalist)
60 media reports of 60 Palestinian suicide bombers (15 of which are incarcerated having been intercepted prior to committing the terrorist act).

Age, gender and educational attainment not stated. versus $\mathbf{2 5 . 4 \%}$ religious had high school education ( $X^{2}$ 35.01, df 2, $P<0001$ ). 5.9\% nationalist vs none of those with religious motivation had tertiary ("academic") education (supporting statistics not provided). Suicide bombers with religious motives more likely to have just elementary education than either high school or tertiary (numbers not presented, OR 8.96, SE 2.19, $\mathrm{P}<0.05$, estimate 2.19 ). Religiously motivated males more likely than nationalist to have prior involvement in terrorist organisations $(36.7 \%$ vs $18.6 \%$ X2 15.1, df 1, $P<0001$ ). Regardless of motivation, Nationalist motivated males more likely to belong to Islamic Jihad (of nationalist motivated: $85.3 \%$ Islamic Jihad, $6.8 \%$ Hamas, $8 \%$ Fatah vs of religiously motivated $59.7 \%$ Islamic Jihad, 32.8\% Hamas, 7.5\% Fatah ( $\mathrm{X}^{2} 18.00$, df 2, $P<0001)$. Females are not represented in Hamas and regardless of motivation more likely to belong to Islamic Jihad: religiously motivated $56.2 \%$ Islamic Jihad, 43.8\% Fatah; nationalist motivated females $64.7 \%$ Islamic Jihad, $35.3 \%$ Fatah (comparative statistics not presented).

Islamic jihad was the most popular terrorist organisation for suicide bomber. Those in Hamas were more likely to be religiously motivated OR 15.30, SE 1.19, P $<0.05$, estimate 2.73

In any case of suicide terrorist attack, there are three conditions shared by all prototypes:

(a) an individual who has at least one motive and is prepared to commit the act (e.g. religious, national liberation) .

(b) a technically based system enabling the preparation and execution of the suicide

attack (e.g. exploitation by the organisation which offers suicide terrorist acts as escape from personal problems, or denies an individual the right to refuse on account of "redemption from sins" such as "homosexuality" or "marital infidelity") (c) the decision of a leading political figure to confirm the use of suicide terrorism e.g. a eulogy by a politician after the death of a suicide bomber (author has just one small explanatory paragraph supporting this asserted condition and is supported with one reference from 2001)

The common supporting factors that were found are:

(1) a sympathetic public atmosphere that praises the sacrifice

(2) media encouragement, ensuring wide coverage both in the Palestinian community and internationally,

(3) spiritual leadership that praises martvrs. and 
30 male and 30 female suicide terrorists (failed and completed) from a wide range of geographical areas and extremist groups: largest group of terrorists involved in IsraeliPalestine conflict. 17 of the females and 22 of the males were from the middle east. biographical accounts of suicide terrorists - open source archival materials (newspaper articles, books, information from the internet). Information about individual terrorists was retrieved from websites compiled by research institutions, think tanks, independent researchers. Websites run by terrorist organisations were also visited. Accounts from perpetrator, family, friends, will documents, videos left by suicide bombers before attacks, media coverage.

Statistical analysis confirmed through qualitative content analysis through grounded theory approach to evaluate differing motivations between female and male suicide terrorists (both failed and completed - referred to in the paper as "unsuccessful" or "successful" suicides). Following motivations were explored:

1.

Religious/nationalistic motivations 2. Persona revenge motivations (e.g. death of a loved one) 3. Peer influences 4. Exploitation
(4) financial support of the family of the deceased suicide terrorist.

The major difference between the various prototypes, in addition to the primary motivating factor and a different trajectory, lies in the unique prerequisite factors

and the relative importance of the supporting factors.

Log-linear analysis found that female suicide terrorists were more likely to be motivated by personal events $(Z=3.01$ ) rather than religious/nationalistic factors $(Z=-3.03)$ and males were more likely to be motivated by religious/nationalistic factors $(Z=3.40)$ rather than personal events $(Z=\mathbf{- 3 . 3 8})$. Females more likely than males to be recruited through revenge motivations ( $Z$ $=1.06$ vs -1.19 )

Unsuccessful (failed) male terrorists more likely than successful male terrorists to have been recruited through peer pressure $(Z=1.86)$

were just as likely to be recruited through peer influence, exploitation, or selfpromotion to the terrorist group. Males were more likely than females to be recruited through religious persuasion. Compared to females, males recruited through peer influence significantly less likely to complete (be "successful") in their suicide attack

"No significant difference" between females and males recruited through exploitation (supporting statistics not stated)
European Jihadists belonging to the

Dutch

"Hofstadgroup" -a socioeconomically diverse group of predominantly young Dutch Muslims who were either the children of Moroccan immigrants, a small number of illegal immigrants from Morocco and Syria, and a "handful" of Dutch converts to Islam. Group included high school students still living with parents, professionals in fulltime work, individuals
Analysis of 'primary sources-based data' on the Dutch "Hofstadgroup" gathered by Dutch national police during their investigation of the group. Data consisted of thousands of pages of information sourced from interrogations of suspects and witnesses, house searches, phone and internet taps in addition to information passed on by AIVD (the intelligence and Security agency of tho Mlothoriandal Mlumhno
Analysis of empirical data on the outcome: to assess rationales that influence the Hofstadgroup to plan and carry out terrorist attacks
Strategic (e.g. a desire to establish theocratic rule in the Netherlands) or organizational (e.g. the group's aim of competing with the State) explanations are not sufficient in explaining the group's planned and perpetrated acts of violence. Rather, most militant participants' motives for terrorism were mostly personal, and not always tied to their extremist religious convictions. A desire for revenge, the emulation of role models and a desire to advocate and defend a new sense of 
interested in

enrolling at

university,

individuals with little

formal education,

and a small number

who depended

financially on the

state and/or friends

and family. Neither

numbers for each

subgroup, nor total

number stated

\section{1 individuals}

involved in

associated with, or

victims of 28 acts of

suicide terrorism

undertaken by

Chechen terrorists

from 2000-2005: 32

close family

members (or close

associates) of 34

suicide terrorists and

2 "would-be-suicide

terrorists"; 4

"seriously

radicalised

individuals who

appeared vulnerable

to becoming suicide

Speckhard \&

Ahkmedova

(2006) terrorists" (2 were additional interviews from the close family members/associates of files not stated. Data

analysis was preceded by

literature review to

develop an 'analytical lens'

to inform the analysis of

the primary data. Method

of data analysis not stated

Semi-structured interviews with close family members and friends ('psychological autopsies') of 34 out of 112 Chechen suicide terrorists. and hostage survivors.

Research interviews conducted by discreet approach to close family members/associates many alluded to above); 11 hostages from the Dubrovka hostagetaking siege. This paper reports 'psychological autopsies' of 34 out of 112 human bombers.

Close family member of whom initially reluctant to grant an interview as nearly all had been visited and interrogated by Russian special services and feared retaliation. Reassured no relationship with security services and that results would be anonymised and published in Western-based journals

Method of analysis not stated

relationships: 2

mothers; 6

sisters/brothers; 7

cousins, aunts,

uncles; 15

neighbours, friends

or teachers (2 not

stated)

Study 1: 9

participants who

were members of

identity as 'true' Muslims all fed into the individual's turn to violence.

Some individuals in Chechnya are vulnerable to self recruitment into suicide terrorist activity in response to traumatic experiences and a sense of duty to avenge combined with exposure to groups that recruit and equip suicide terrorists with both an ideology and the means to commit the suicide terrorist act. The

Exploration of terrorist family life, psychosocial history, life events prior to becoming terrorists, personality and behavioural changes, psychological state and possible motivations. Data analysed for organisation, individua and societal motivators for suicide terrorism in Chechnya.

Study 1 To understand How the radical groups think, and how such thinking can lead to sacred violence. Interviews guided by 4 key questions: What ideology supporting Chechen suicide terrorism is very similar to the Salafi global jihadist ideology but remains more nationalist in its goals i.e. to force withdrawal of all Russian military and security forces from Chechnya, to gain national independence, gain amnesty for prisoners of war. Increasingly as the Chechen terror network has become more closely aligned in funding and ideology to the global jihad - to be left free to establish and Islamic State.

It functions for the bombers much like short lived psychological first aid answering their posttraumatic concerns in a way that shortly leads to their deaths. Unlike the Palestinian setting (where there is over $\mathbf{5 0} \%$ societal support for terrorism), there is little social support for suicide terrorism in Chechnya. 
Indonesia's radical Islamist groups; 6 people of the Jamaah Ansharut Tauhid (JAT) from Surakarta, Central Java; 3 people of the Islamic Defender Front (FPI), Jakarta.

Study 2: National representative sample. 1320 Indonesian citizens of which 1144 were Muslims. Mean age 39.9 years (SD 13.4, range $16-97$ ). $52 \%$ male. Majority had Iow educational achievement: $17 \%$ never finished elementary school, 49.7\% never finished junior high school, $71 \%$ never completed senior high school $92 \%$ never or yet to finish higher education. $62 \%$ had a monthly income of less than 1 million rupiahs (equivalent to about 111 US dollars), $23 \%$ had an income of between 1 and 2 million rupiahs with "the rest" (15\%) earning more than 2 million rupiahs.
Milla et al

(2013)
5 males involved in

Bali Bombings - 2 males considered Leaders, 3 males considered Followers concept of jihad does the group hold?; How does the group see the relation between Muslim and nonhow does the group see the Al-Qur'an and its

teachings?; How does the group see Sharia and its relevance to the modern world?

Study 2: Cross sectional survey. Sampling frame constituted completers of a "representative national survey" conducted in March 2010 by Indonesian Survey Institute. Potential participants excluded if more than 3 missing answers in completing the "representative national survey", leaving 934 participants. Eligible participants needed to have election voting rights i.e. either above 17 years of age or married.

Multi-stage random sampling to select participants who were then interviewed by a trained interviewer.

Interviews, observation and close readings of documents (including previously unavailable primary sources such as personal letters, in addition to published materials written by or about the perpetrators i.e. letters from perpetrators to family members; handwritten wills; unpublished manuscript of a biography; manuscripts of public statements including a published

Study 2: Quantitatively test the hypothesis generated in Study 1 by structural equation modelling of the mediating role of jihad by the following six latent variables:

intratextual fundamentalism; religiosity; perception of unfair treatment; support for Islamic law belief in violent jihad; sacred violence.

Instruments used to measure the six latent variables were:

Intratextual

Fundamentalism Scale; Religious Practice Scale; Unfair Treatment Scale; Support for Islamic law (Sharia) Scale; ; Belief in Violent Jihad Scale; Sacred Violence Scale.

"Correlation analysis" undertaken using LISREL 8.71 software.
Exploring the social contexts in which leader-follower relationships played a critical role in violent radicalisation with respect to the Muslims nowadays?;
Study 1. Following themes emerged as mediating factors in violent jihadism (as expressed in sacred violence in Indonesia:

1. Intratextualism i.e. sacred text perceived as divine or inerrant, selfinterpretive, privileged, authoritative, unchanging

2. perception of unfairness, (i.e. perceived historical injustices of Dutch occupation and also the removal of Jakarta Charter [a mandate for imposition of Islamic Law] as ending an Islamic government system) and religious practice leads to support for Sharia and a belief in Violent Jihad which leads to violent jihad (expressed in the Indonensian cultural context as sacred violence)

Study 2. Fit indices of the confirmatory factor analysis Only violent jihad had a significant relationship with sacred violence $\left(X^{2}=346.19\right.$ [d.f. $=257$; Sig.0.00], RMSEA=0.019 (Sig. 1.00), AGFI=0.96, $\mathrm{NFI}=0.95)$. However, authors highlight the limitations of the factor analysis and from the data argue a complex interrelationship between intratextual fundamentalism; religiosity; perception of unfair treatment; support for Islamic law; belief in violent jihad; lack of education and the practice of sacred violence
Pre-radicalisation: environmental conditions that allowed for exposure to radical ideology (environmental conditions are life situations that support socialisation and internalisation of a particular set of Islamist values including exclusivism and the centrality of struggle. Occurs in family and educational settings and had been a feature of the perpetrators environments since childhood.

Self-identification: adjustment of one's identity upon internalisation of Islamist values - described as "religious seeking" that is influenced by both internal and external factors, in particular adopting an understanding of Islam as a way of life. informed through the experience of 
book; video and audio recordings of interviews with authorities and sermons delivered by perpetrators while in custody).

Data analysed by narrative analysis in the early stage and then combined with thematic analysis
Inqonesıan balı bombers.

Demographic details not reported in the paper. Rather reported that it's a "re-analysis of Sageman's (2004) and Pape's (2005) data predicting Al'Qaeda membership and suicide terrorism."

Sageman reported descriptive statistics on data in the public domain pertaining to 172 Salafi mujahedin terrorists on whom there was sufficient

background information pertaining to age, ethnic background ("origin"), religious commitment and educational attainment. Jihadists divided into separate clusters:); Southeast Asian (21); Maghreb (53); and Core Arab (66). Also "Central Staff” (32): 20

Egyptian, Saudi Arabia (3), Kuwait (3), Jordan (2), Iraq, Sudan, Libya and Lebanon (1 each). Age and gender not stated.
Re-analysis of two secondary datasets
Pape reported descriptive statistics on data in the public domain pertaining to every suicide terrorist attack globally from 1980 to 2003 - a total of a ...
Ordinary least squares regression analysis to predict

the number of Al'Qaeda suicide terrorists and A17Qaeda membership from (a) total Muslim population, total Salafi population, U.S. combat presence, and U.S. political backing (U.S. Regime Support) for the national

regimes (Model A) or, (b) the total Muslim population, total Salafi population, personal conflict/crisis

Commitment and Indoctrination: Links with Jihadi groups through a mentor and who organised the departure of jihadists from Indonesia to Afghanistan, Moro and other fields of conflict

Jihad ideologization: Jihad is articulated as struggle in the way of God and translates specifically to the struggle of Islam as articulated by the leader. Disciples follow the fatwa and willingly participate in jihad without question.
Confidence intervals not reported. "Total Muslim population negatively related to

both outcomes" i.e. suicide terrorism (-.34, $P$ value not stated in model $A ;-.35, P$ value not stated in model B), Al'Qaeda membership (-.53, $P$ value $<0.05$ in model $A ;-.31, P$ value not stated in model $B$ ). "Salafism does appear to be related to membership clearly but is not significantly related to terrorism" i.e. for suicide terrorism (.33, $\mathrm{P}$ value not stated in model $3 a$ $A ;$.33, $P$ value not stated in model $B$ ), Al'Qaeda membership (.46, $\mathrm{P}<0.05$ in model $A ;$.48, $P<0.05$ in model $B$ ).

"US combat presence or US regime support" predicts both suicide terrorism (0.46, $\mathrm{P}<0.05)$ and Al'Qaeda membership $(0.45, P<0.05)$ 


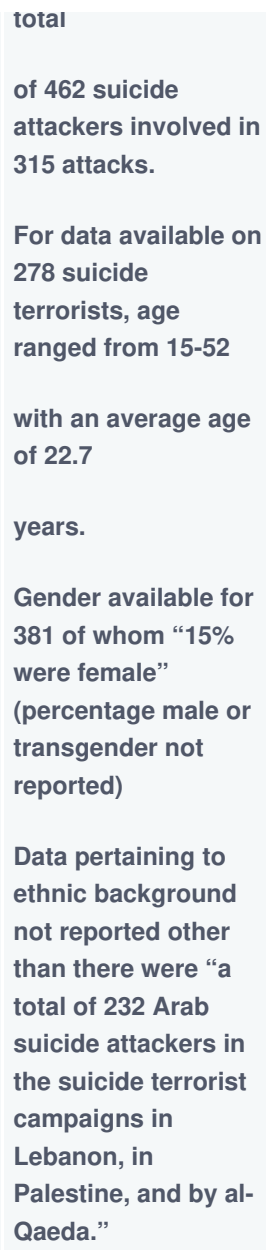

and either U.S. combat

presence or U.S.

regime support (Model

B).

\section{Results}

Figure 1 highlights that 1275 potentially relevant papers were identified. 823 articles were excluded at the title and abstract screening stage, and 35 articles were obtained and screened in full. 23 papers were subsequently excluded, leaving 12 studies included in the review. A summary of each of the papers is presented in Table 1. Core themes are presented below, subdivided into individual characteristics of terrorists and socio-cultural (including political) characteristics as possible explanators of causal pathway into terrorism.

\section{Individual Characteristics}

Our review highlighted individual characteristics which are presented below.

\section{Age and Gender Characteristics}

Jacques and Taylor ${ }^{[19]}$ explored biographical accounts in the public domain of 30 male and 30 female suicide terrorists (both failed and completed suicides), from a wide range of geographical areas and extremist groups involved in the IsraeliPalestine conflict. Regarding ethnic background, 17 of the females and 22 of the males were from the Middle East. Key 
findings were that female suicide terrorists were more likely to be motivated by personal events and males were more likely to be motivated by religious/nationalistic factors. Females and males were just as likely to be recruited through peer influence, exploitation, or self-promotion. Males were more likely than females to be recruited through religious persuasion. Compared to females, males recruited through peer influence were significantly less likely to be "successful" (i.e. commit suicide). The authors postulate the difference could be due to the fact that some recruitment tactics are more effective than others at moving an individual to a point where socially and personally they are prepared to carry out and complete an attack. Alternatively, they suggest it may be the case that recruitment strategies are better at recruiting different types of individuals, and that males recruited through peer pressure are not people whose character is "suited" to suicide terrorism. They argue given significant evidence to suggest that there is no one profile for a suicide terrorist; the finding seems to suggest the former possibility is the most likely explanation.

The finding that in the Palestinian context, compared to females, males were more likely to be recruited into terrorist networks through religious motivations was confirmed by Sela-Shayovitz ${ }^{[20]}$, who undertook secondary data analysis of 294 media reports of suicide bombers published in 3 major daily newspapers in Israel between 2002 and 2005. In the cases in which the motive was clear, the author found that males were more likely than females to have religious rather than nationalist motivation. It was also found that those with nationalist motivation had a higher level of educational attainment. Religiously motivated males were more likely than nationalist motivated to have had prior involvement in terrorist organisations. The research explored affiliation to the following organisations: Islamic Jihad, Hamas or Fatah. The key finding was that Islamic Jihad was the most common affiliated organisation regardless of both gender and whether the motivation was religious or nationalist. Counter-intuitively, those in Hamas were more likely to be religiously motivated.

Dalton and $\mathrm{Asal}^{[21]}$, in undertaking secondary data analysis of three databases, to explore why organisations deploy women in violent terrorist attacks, found higher educational attainment statistically significantly correlated with involvement in terrorist related activity. Further, they reported women's social rights to be negatively related with participation in terrorist activity, i.e. where women are socially empowered and autonomous, they are less likely to be involved. Both larger size and age of the terrorist organisation positively correlated with female involvement. At the level of the population, energy consumption per capita also positively correlated with female involvement in terrorist organisations ${ }^{[21]}$. The authors suggest that the fact that larger organisations are more likely to recruit and deploy women may be driven by staffing needs in larger organisations. Alternatively, they suggest that it could be a result of their greater capability to adapt to or adopt new strategic activity and, therefore, female recruitment is more feasible due to their versatility. Regarding age of the organisation, the authors suggest that this could be related to prolonged ethno-religiousnationalist struggles that have far reaching mobilising consequences for both men and women. Therefore, over time women feel an affinity to the objectives of the terrorist organisation. Alternatively, they suggest the reason could be a tactical evolution over time toward incorporating women as low-cost and high impact attacking apparatus as an organisational response to stagnation in performance and an escalation in frustration resulting from setbacks. Regarding the positive correlation between energy consumption and involvement in terrorist activity, the authors suggest that whilst such economic development affords education for women it does not necessarily afford gender equality and that in such 
situations there is a risk of women joining terrorist organisations from a motive in part to realise better rights for women. They do acknowledge that it is just a crude measure. Therefore, we conclude it is possible that such findings could be further examples of ecological fallacies, whereby the finding at the level of the "group" (in this instance a "country") does not necessarily hold for the individual within the group.

\section{Sociocultural Characteristics}

Religious versus Nationalist Motivations: are they mutually exclusive?

Muluk et al. ${ }^{[22]}$ undertook qualitative interviews with both members of Indonesia's radical Islamist groups and a representative sample of the population in Indonesia that were eligible to vote. They explored mediating factors in the practice of "sacred violence." Sacred violence is defined as criminal action which is claimed to be based on religious ideals and is dedicated to defend what is sacred or to punish any violation of what is perceived as divine law. Findings from the qualitative study suggested two themes as mediating factors in "violent jihadism," which the authors expressed as sacred violence in Indonesia. Firstly, the authors describe the mediating factor of "intratextualism," wherein sacred text is perceived as divine, inerrant, self-interpretive, privileged, authoritative and unchanging. Secondly, the authors describe a "perception of unfairness" as a mediating factor. Such beliefs in the Indonesian context were described as a grievance against perceived historical injustices of Dutch occupation, and also the removal of Jakarta Charter [a mandate for imposition of Islamic Law] as ending an Islamic government system. The authors concluded that such a grievance regarding perceived unfairness together with a religious view of intratextualism leads to support for Sharia and a belief in the legitimacy of violent Jihad. Such a belief in turn leads to acts of violent jihad through an expression of sacred violence.

Such findings concur with those of Milla et al[?23], who undertook thematic analysis of interviews, observation and close readings of "documents" in connection with five male terrorists involved in the Indonesian Bali bombing. Such "documents" included previously unavailable primary sources such as personal letters, in addition to published materials written by or about the perpetrators. Published materials included letters from perpetrators to family members; handwritten wills; unpublished manuscripts of a biography; manuscripts of public statements including a published book; and video and audio recordings of interviews with authorities and sermons delivered by perpetrators while in custody. In exploring the social contexts in which leader-follower relationships played a critical role in violent radicalisation of the bombers, the authors described a psychosocial process of pre-radicalisation, self-identification, commitment and indoctrination leading to "jihad ideologization" (see Table 1). Pre-radicalisation comprises a set of environmental conditions that allows for exposure to radical ideology. These are life situations that support socialisation and internalisation of a particular set of Islamist values including exclusivism and the centrality of struggle. The researchers found that such conditions occur in family and educational settings and have been a feature of the perpetrators' environments since childhood. Such conditions then lead the individual into a phase of "self-identification" whereby one's identity is rooted in internalisation of Islamist values. This is described by individuals as "religious seeking" that is influenced by both internal and external factors, in particular, adopting an understanding of Islam as a way of life. Such a process is sometimes informed through 
the experience of personal conflict or crisis. Such "religious seeking" can then place the individual as vulnerable to indoctrination once linked with Jihadi groups through a mentor. In the specific Indonesian context of the Bali bombings, the mentor organised the departure of jihadists from Indonesia to Afghanistan, Moro and other fields of conflict. At this point the individual has adopted a state of "Jihad ideologization," in which Jihad is articulated as struggle in the way of God. This ideology translates specifically to the struggle of Islam as articulated by the leader. The individual is then a "disciple" following the fatwa and willingly participating in jihad without question.

Schumm et al. ${ }^{[24]}$ undertook a re-analysis of previously reported descriptive data ${ }^{[25][26]}$ predicting Al'Qaeda membership and suicide terrorism. They explored the predictive value of the following: total Muslim population, total Salafi population, U.S. combat presence, and U.S. political backing (U.S. Regime Support) for the national regimes. They concluded that "total Muslim population" was negatively related to both outcomes, that Salafism does appear to be related to Al'Qaeda membership but not significantly related to terrorism. They further concluded "US combat presence" or "US regime support" predicts both suicide terrorism and Al'Qaeda membership. Therefore, the Schumm et al. findings do not concur with the Muluk et al. and Milla et al. findings above in that they reject potential religious motivators for terrorism in suggesting Western military involvement as the causal factor. This is likely due to methodological flaws in Schumm et al research. The research appeared to adopt an ecological study design (although it was not reported as such) but had several significant limitations ${ }^{[24]}$. First, there appeared to be data dredging with poor justification. For example, the authors state: "present regression models were run with and without including data from Saudi Arabia since that nation had by far the largest number of suicide terrorists in the data set." Also used were models with "percentage of Salafi population" instead of "total Salafi population." Second, supporting confidence intervals are not presented for standardized beta results of ordinary least squares regression analysis. Therefore, it is possible that the findings were in fact an example of the "ecological fallacy" in that that relationships observed in groups does not necessarily hold for individuals (see discussion section below). That said, as presented below, the findings from our review would suggest validity to Schumm et al. findings of Western military involvement in Muslim majority countries as a causal factor in religiously inspired terrorism through contributing to a sense of grievance. This theme will be explored further in the following sections.

\section{Western "homegrown" Terrorism}

The findings from the research conducted by Bartlett \& Mille ${ }^{[27]}$ explored profiles of three groups. They were defined as: "homegrown" Western terrorists, radicals and young Muslims. Their findings highlight the difficulty in defining pathways into terrorism since they conclude many characteristics of terrorists can be applied more widely, to non-violent radicals. For example, both groups were strongly untrusting of government, possessed a deep outrage with Western foreign policy and held a perception of social discrimination. Further, both groups had psychological and emotional experiences of drift and uncertainty regarding their own identities, Also, both groups showed some desire of a caliph or Islamic government being created. They also spoke of the benefits of some form of self-segregation in societal structure (e.g. separate schools NEED TO CHECK) and had a theological attachment to just war theory (i.e. a war that can be justified ethically as a "lesser of two evils"). However, they highlighted terrorists differed from young Muslims and radicals in that the former displayed non-participation in government elections, democracy or the judicial system. Further they do not engage in 
peaceful protest. By contrast, unlike terrorists, many radicals channel their energy through community work to support the communities they conceptualise as oppressed (for example counselling prisoners in a local prison or travelling to Afghanistan to participate in community work).

In the Bartlett \& Miller ${ }^{[27]}$ research further differences between the groups was found in the area of education whereby, compared to radicals, terrorists had slightly lower levels of education, were less likely to be employed, were more likely to have dropped out of education, were less likely to have studied the humanities and more likely to have studied the vocational sciences (for example IT, business or engineering). Regarding religious Identity, across all groups there was a belief expressed of exploring inherent tensions of dual identity i.e. difficulties reconciling Islamic heritage with Western society leading to an extremist ideology providing a clear (albeit negative) identity. Religious adherence was adopted as it presented a set of norms that reduces uncertainty. Religion provided a clear set of answers, with structures and rules to follow. Whilst such beliefs were unanimous across the sample, a number of radicals reported embracing a devout, but peaceful, Islam during a period of contemplation. Further, whilst religiosity of upbringing did not differ significantly between terrorists and radicals; radicals were more likely than terrorists to have undertaken personal study into Islamic history and jurisprudence. Radicals conceptualised Islamist terrorists as "warped" and "shallow and baseless" and "not even knowing Islam". They expressed a view that terrorists were unwilling to engage in critical thinking with a "blind adherence" to "literalism." Literalism was expressed as an unwillingness to consider the importance of context, particularly in interpreting the so-called "blood verses" in sacred texts, which make reference to religiously motivated violence.

The researchers also explored religious concepts of "takfir" and "kafir." The former is accusing other Muslims of apostasy punishable by death and the latter is a reference to a "non-believer" (plural is kuffar). All groups supported the concept of Kuffar and that some form of segregation in society between believers and non-believers can be beneficial. Regarding findings from exploring the concept of "takfir", findings were not reported in the paper.

Concepts of the Caliphate and Sharia Law were explored with a finding that re-installing a caliphate, and imposing such in Europe, were popular concepts amongst both radicals and terrorists. However, radicals tended to view such an aspiration as an impracticable, un-realizable dream. Also introducing Sharia law was seen as desirable amongst both radicals and terrorists. However, the former view it as an aspirational ideal and a system that helps Muslims to live by a moral code, rather than a system of oppression.

Regarding theological scholars as role models and interpreting religious texts, terrorists typically drew upon a narrow band of thinkers. Four names from historical Islamic scholarship were frequently cited. Radicals were also familiar with such authors. However, the latter were more able to interpret the historical context in which such scholars were writing. For example, radicals were more able to interpret the harsh ideas expressed by the authors as a response to the imprisonment and torture they were experiencing at the time in history when they were writing.

Finally, the concept of Jihad in both the West and East were explored and terrorists conceptualised Jihad as a legitimate response to defending Islam and the Ummah (the world's Muslim community) which is under attack. Such a view was shared by young Muslims and radicals who portrayed "Defensive Jihad" as a matter of fairness and self-defence of one's land, property, religion and family. In essence, their belief was that Jihad was no different to any other "just war", and they 
drew comparisons with French resistance during the second world war. Radicals reported not seeing Islam as a religion of peace, but a religion based upon justified violence and the long tradition of just war theory.

The extensive findings described above by Bartlett and Miller largely concur with those reported by Schuurman \& Horgan ${ }^{[28]}$ who undertook an analysis of primary data gathered on the Dutch Jihadist "Hofstadgroup" by national police during their investigation of the group. Data consisted of thousands of pages of information sourced from interrogations of suspects and witnesses, house searches, phone and internet taps in addition to information passed on by AIVD (the intelligence and Security agency of the Netherlands). They highlighted strategic Islamist (e.g. a desire to establish theocratic rule in the Netherlands) and organizational (e.g. the group's aim of competing with the State) motivators for terrorism but concluded that neither explanations are sufficient in fully explaining the group's planned and perpetrated acts of violence. Rather, most militant participants' motives for terrorism were largely personal, and not always tied to their extremist religious convictions. A desire for revenge, the emulation of role models and a desire to advocate and defend a new sense of identity as 'true' Muslims all fed into the individual's turn to violence.

Research undertaken by Speckhard \& Ahkmedova ${ }^{29]}$ also reported a desire for revenge. The researchers had privileged access to undertake interviews with 51 individuals involved in, associated with, or victims of 28 acts of suicide terrorism undertaken by Chechen terrorists between 2000 and 2005. Their objectives were to explore terrorist family life, psychosocial history, life events prior to becoming terrorists, personality and behavioural changes, psychological state and any other possible motivations. Data was analysed for organisation, individual and societal motivators for suicide terrorism in Chechnya. Key emerging themes were that some individuals in Chechnya are vulnerable to self-recruitment into suicide terrorist activity in response to traumatic experiences and a sense of duty to avenge. Such personal motivators combined with exposure to groups that recruit and equip suicide terrorists with both an ideology and the means to commit the suicide terrorist act are significant pathways into terrorism. The authors highlighted the ideology supporting Chechen suicide terrorism as very similar to the Salafi global jihadist ideology but remains more nationalist in its goals i.e. to force withdrawal of all Russian military and security forces from Chechnya, to gain national independence and amnesty for prisoners of war. Writing in 2006, they concluded that increasingly the Chechen terror network has become more closely aligned in funding and ideology to the global jihad with a desire to establish an Islamic State. For the suicide bombers, they view their proposed terrorist activity as "psychological first aid" by answering their posttraumatic concerns in a way that shortly leads to their deaths. However, unlike the Palestinian setting (where there is over $50 \%$ societal support for terrorism), there is little social support for suicide terrorism in Chechnya. The relationship between Palestinian and wider Middle East geopolitics to terrorist activity will now be discussed in the following section.

\section{Middle Eastern Geopolitical Factors}

Kimhi \& Even ${ }^{[30]}$ analysed 60 media reports of 60 Palestinian suicide bombers (15 of which are incarcerated having been intercepted prior to committing the terrorist act). They concluded that in the Palestinian context, in any case of suicide terrorist attack, there are three conditions shared by all prototypes. First, the individual has at least one motive and is prepared to commit the act, with the most commonly reported motives being either religious or national liberation. Second, 
there needed to be a "technically based system" (a terrorist group) enabling the preparation and execution of the suicide attack. The group can exploit vulnerability from personal problems and offer a "solution." For example, it can deny an individual the right to refuse on account of portraying an act of suicide bombing as "redemption from sins" such as "homosexuality" or "marital infidelity." It can also exploit minors, with reports of school-age children as young as fourteen being involved in such attacks. Third, there needs to be political support confirming the use of suicide. Such support can either be direct or indirect, for example a eulogy by a politician after the death of a suicide bomber. Further, the authors highlighted supporting factors that contribute to a culture supportive of terrorism. Such socio-cultural factors included: a sympathetic public atmosphere that praises the sacrifice; media encouragement, ensuring wide coverage both in the Palestinian community and internationally; spiritual leadership that praises martyrs; financial support of the family of the deceased suicide terrorist. These findings by Kimhi and Even ${ }^{[30]}$ concur with those of Speckhard \& Ahkmedova ${ }^{29]}$ in highlighting the widespread public and political support within Palestine for suicide terrorists.

Outside of Palestine, Middle Eastern political factors appear to be a contributing factor towards extremist beliefs as highlighted in two studies recruiting Muslim students in Pakistan ${ }^{[31]}$. The authors, Amjad \& Wood, explored attitudes towards anti-Semitic aggression. The first study comprised a survey exploring behavioural intent to join an extremist organisation described as defending Muslim identity and honour by opposing and fighting enemies of Islam such as those of Jewish heritage. They found that those requesting to join the extremist group were more likely than refusers to have normative anti-Semitic aggressive beliefs. They also found that those who moved beyond requesting to actually join were more likely than refusers to have normative anti-Semitic aggressive beliefs.

In the second study the researchers randomly allocated participants to one of two groups - either a brief educational intervention comprising Muslim-Jewish relations delivered by a British Pakistani psychologist, or to a control group comprising a normal lecture on cognitive behavioural therapy which made no mention of aggression or Jewish culture. Three days later participants were approached to join the extremist group outlined above in the first study. Participants in the control group were more likely to both request information and agree to join the extremist group. There was no effect of gender upon either requesting information or joining. The authors concluded that the effectiveness of the educational intervention was mediated by changes in normative beliefs regarding aggression against those of Jewish heritage.

\section{The Impact of Prison Setting}

Our review retrieved just one study that met the inclusion criteria and which explored the impact of the prison setting upon recruitment into terrorist networks. This was US based research conducted by Hamm et al. ${ }^{[32]}$, who interviewed prison chaplains, gang intelligence officials, analysts from the FBI's National Joint Terrorism Task Force, and prisoners. The objective was to explore why prisoners convert to Islam and the impact upon inmate behaviour; the relationship between Islam, radicalisation and gangs; the process of moving from radicalised beliefs to terrorist acts. Key findings were that although the motivation for some prisoners to convert to religion is personal crisis, or need for protection, the primary reported reason was spiritual searching, i.e. seeking religious meaning to interpret and resolve discontent. Such converts reported experiencing self-discipline to help interact in a positive manner. However, for some converts, there was a potential for radicalisation through a strong collective group identity which facilitated carrying out directives from their 
leaders. This was particularly a phenomenon in maximum-security prisons (e.g. a response to grievances "against the US government for killing innocent civilians in Iraq, and mistreating Muslims at Guantanamo Bay"). The author concluded that traditional American Islam exposed to a prison inspired Prison Islam, fused with the opportunity for prison gang membership, provided members with identity, meaning and a collective grievance against the social forces responsible for their imprisonment.

\section{Discussion}

\section{Religion or nationalism?}

Our review retrieved a number of papers pertaining to the phenomenon of Islamist inspired terrorism and highlighted both religious and nationalistic factors contributing to terrorist activity. Religious motivators were particularly apparent in the form of "intratextualism," wherein sacred text is perceived as divine, inerrant, self-interpretive, privileged, authoritative and unchanging. Such a view can contribute to terrorist activity when individuals are either unable, or unwilling, to consider the importance of historical context in interpreting writings within sacred texts which refer to religiously motivated violence. Further, for some individuals, life situations support socialisation and internalisation of a particular set of Islamist values which include exclusivism and the centrality of struggle. For those who commit terrorist acts, such conditions often occur in family and educational settings and have been a feature of their environments since childhood. If linked to traumatic events, this can lead to a sense of grievance, leading the individual into a phase of "self-identification" whereby one's identity is rooted in internalisation of Islamist values. For Islamist terrorists, Western military involvement in Muslim majority countries contributes to a sense of grievance and is often linked with a desire for a caliph or Islamic government being created.

\section{Educational Attainment}

Level of educational attainment is not a critical causal link togeneric terrorist activity, as emphasised by the findings reported by Sela-Shayovitz ${ }^{[20]}$. They highlighted both religious and nationalistic motivators for terrorist activity. However, they found that a lower level of educational attainment did predict religiously motivated terrorism. Such a finding of lower educational attainment for those with religious motivators for terrorist activity concurs with the findings of both Bartlett and Miller and Muluk et al. ${ }^{[22][27]}$. The findings of Milla et al. suggest that such religiously motivated terrorists tend to have been exposed to extremist ideologies through childhood family and educational influences ${ }^{[23]}$.

This finding also concurs with the sociological critique of the relationship between religious belief and political processes in the USA, whereby commentators highlight the inherent anti-intellectual stance of religious fundamentalists in, for example, their attacks on the teaching of Darwinian evolution in schools. He also highlights anti-intellectual behaviours of such fundamentalists in ignoring the findings of scientific research as evidenced by spreading misinformation that abortion causes breast cancer, exaggerating the failure rates of condoms, and viewing Middle Eastern conflict in Iraq as an opportunity to disseminate a Christian theology in the country ${ }^{[33]}$. 
Encouragingly, our review retrieved research undertaken in Pakistan which highlighted the positive impact of education upon changing religious extremist beliefs ${ }^{[31]}$.

\section{Prisons}

Our research highlighted that the settings of prisons could form a focus for counter-terrorism activity, and this is confirmed by emerging evidence from case studies ${ }^{[34]}$. Based upon a review of case studies in 15 countries the author highlights the vulnerability of prisoners to radicalisation on account of convicted terrorists using their time in prison to mobilise outside support, radicalise other prisoners and - if given the opportunity - to attempt to recreate operational command structures. In response, many of the countries practice a policy of dispersal and (partial) concentration of such prisoners among a small number of high security prisons. The authors highlight the potential for collective group disengagement from the terror network but highlight that such acts are rare and predicated upon the existence of strong and authoritative leadership; the existence of hierarchical command and control structures; and not least a conducive environment in which the leadership perceives that the armed campaign has faltered or is seen to become less useful than other means of contention. More commonly programs focus upon individual dis-engagement (also referred to as de-radicalisation). Key components appear to be a mix of different kinds of programming, typically combining ideological and or religious reeducation with vocational training; credible interlocutors who can relate to prisoners personal and psychological needs; emphasis upon prisoners transition back into mainstream society, typically by providing them with the means for a new beginning and by establishing social networks away from extremism; sophisticated methods for locking prisoners into multiple commitments and obligations towards family community and the state; inducements, which although useful do not appear to be decisive on their own.

Such findings concur with the generic literature pertaining to disengagement from both religious and non-religious extremist groups. For example, a US based study of 34 former white supremacists who had exited such an extremist movement explored the psychological and behavioural processes influencing such a decision to disengage ${ }^{[35]}$. The authors drew parallels with individuals leaving either criminal gangs or religious cults. Members of cults must adhere to strict rules of conduct which are intended to reinforce ideological commitment. For those who exit, the process begins with psychological changes that involve questioning and challenging fundamental beliefs of the movement. Doubts take the form of "cognitive restructuring" in which the movement and ideology is viewed differently and in a more detached fashion. Behavioural changes which lead to disengagement are characterised by publicly discussing doubts, changing scripts or styles of speech, spending increased amounts of time with external influences, and physical withdrawal from the activities of the group. Such a process leads to a weakened support system and a feeling of alienation from other members in the group, leading to exit from the group ${ }^{[36]}$. The authors highlighted a process of exit from white supremacist movements which was facilitated, in part, through self-reflection that results from contact with law enforcement and the negative experience of imprisonment. Such negative experiences may provide an impetus for change as a result of "hitting rock bottom". However, the authors illustrated the difficulties associated with the exiting process. Specifically, former members mentioned enduring feelings of guilt, ideological relapses into previous ways of thinking, and ongoing contact with active 
members of the white supremacist movement. Their findings highlighted the need for ongoing psychological treatment to support extremists who have disengaged to address ideological relapses and any problems associated with mental health.

These findings of the need for psychological support for those who disengage from extremist groups raise public health implications internationally, not least because there has been a significant decline in the influence of ISIL on account of its failed attempt to create an Islamist caliphate in the Middle East. Compared to the previous year, Iraq recorded over 5,000 fewer deaths from terrorism in 2017, while Syria recorded over 1,000 fewer deaths ${ }^{[1]}$. Overall, the number of deaths from terrorist attacks attributed to ISIL fell by 52 per cent in 2017, with reports of jihadists from diaspora communities wishing to return from the sites of Middle Eastern conflict to their Western country of origin ${ }^{[37][38]}$.

\section{Methodological Limitations}

There appeared to be significant methodological limitations with much of the published evidence reported in this review. In particular, the reported quantitative research studies appeared to have flaws in both design and analysis. For example, the finding by Muluk et al. ${ }^{[22]}$ that only "violent jihad" had a significant relationship with "sacred violence" raises an epistemological question as to whether these social constructs are in fact discrete. It would appear to the reader that they are not and therefore there is a tautology to the theory that only "violent jihad" was related to "sacred violence." Also, the authors failed to clearly articulate their rationale for the statistical tests used. For example, the authors undertook confirmatory factor analysis on the six latent variables when it could reasonably be argued that exploratory factor analysis is more appropriate in the early stages of scale development ${ }^{[39]}$. Further, the findings by both Dalton \& Asal and Schumm et al. ${ }^{[21][24]}$ highlights the need to be extremely cautious in interpreting the findings of ecological studies, since an "ecological fallacy" can easily arise from asserting that relationships observed for groups necessarily hold for individuals ${ }^{[40]}$. It would appear that such bias is apparent in Schumm et al.'s analysis. For example the "total Muslim population" was reported as negatively predicting membership of an Islamist terrorist organisation (i.e. Al'Qaeda) which did not triangulate with other findings in our research. Also, the finding by Dalton \& Asal[ ${ }^{21]}$ that energy consumption per capita positively correlated with female involvement in terrorist organisations was not confirmed by other research and could be a further example of an ecological fallacy.

\section{Conclusion: towards a comprehensive conceptual model to explain religiously inspired}

\section{terrorism}

In conclusion, the concept of religiously motivated terrorist activity will, for the foreseeable future remain contested, since there appears to be a dearth of high-quality empirical literature to support the plethora of theoretical frameworks seeking to explain the phenomenon of terrorism, which itself defies a full definition ${ }^{[2]}$. Such a dearth is, in part, because researchers in this field are rarely permitted direct access to either terrorists or confidential government reports on terrorist activities due to extreme sensitivities of the subject matter. Therefore, empirical research tends to focus upon information in the public domain ${ }^{[25]}$. Further, if such privileged access to terrorists were granted, there remains a significant barrier 
regarding potential non-disclosure of true motives by convicted terrorists since such disclosure could threaten the objectives of the wider terrorist network. Therefore, faced with such ontological barriers we would cautiously suggest that rather than seeking to understand the nuance regarding causal links for apparent religiously inspired terrorism, resource would be better placed in understanding how vulnerable individuals can be prevented from joining such networks, or for those who have joined, supported to leave. Religious belief may have a part to play in fulfilling such objectives. For example, research conducted amongst Pakistani university students exploring coping with the negative impacts of terrorism highlighted how religious commitments were a coping mechanism ${ }^{[41]}$. Therefore, despite the current international phenomenon of religious terrorism being Islamist inspired, we would caution against "demonising" one particular faith group as more at risk of promoting terrorist activity than another. On account of the time period of 20012018 from which published research was retrieved to inform our review, all papers exploring religiously inspired terrorist activity pertained to Islamist terrorism. However, there is evidence from the field of forensic psychology, supported by both an ancient and modern historical narrative, regarding religiously inspired violence being associated with distorted offshoots of all the major world religions ${ }^{[7][8][9]}$. The key point appears to be that at various times throughout history, some adherents to all of the worlds' religions have at times distorted teachings and, from a position of perceived religious piety, engaged in violent acts for what they perceive to be a 'noble cause.' In terms of a credible response to the threat of religiously inspired terrorism, our review would suggest it would be too simplistic to posit that such terrorists believe they are acting from a "divine order" of a deity. Rather, literal interpretation of sacred texts that make reference to violence, associated with a grievance regarding Western military involvement in Muslim majority countries, can lead to a desire for revenge and an aspiration for an Islamic governed caliphate, which terrorists believe is both practicable and noble.

\section{References}

1. ${ }^{a, b}$ Institute for Economics \& Peace. (2018). 2018 Global Terrorism Index: Deaths from terrorism down 44 per cent in three years, but terrorism remains widespread.

2. ${ }^{a, b}$ (2011). Interlocutory Decision on the Applicable Law: Terrorism, Conspiracy, Homicide, Perpetration, Cumulative Charging, STL-11-01/1.

3. ^Kamaruzaman Yusoff. (2010). Islamic Radicalism in Malaysia: an overview. Procedia-Social and Behavioral Sciences, vol. 5 .

4. 'Arun Kundnani. (2015). A Decade Lost: Rethinking Radicalisation and Extremism. Claystone.

5. ^Robert Pape. (2008). Dying to win: The strategic logic of suicide terrorism. In The theory and practice of Islamic terrorism. Palgrave Macmillan.

6. 'Mohammed Hafez. (2008). Radicalization in the Persian Gulf: Assessing the potential of Islamist militancy in Saudi Arabia and Yemen. Dynamics of Asymmetric Conflict, vol. 1.

7. a, berrold Post. (2007). The mind of the terrorist: The psychology of terrorism from the IRA to Al-Qaeda. Palgrave Macmillan.

8. a, b Jonathan Sacks. (2015). Not in God's Name: Confronting Religious Violence. Hodder \& Stoughton Ltd..

9. ${ }^{a}, \mathrm{~b}$ Thomas Sizgorich. (2009). Violence and Belief in late antiquity: militant devotion in Christianity and Islam. University 
of Pennsylvania Press.

10. ^Nat Wright. (2016). Can religious fundamentalism reform for the benefit of public health? In search of commonality in the lay literature to counter the threat of violent extremism. British Journal of General Practice, vol. 66 .

11. ^Walter Reich. (1998). Origins of Terrorism. Woodrow Wilson Center Press.

12. 'Centre for Reviews and Dissemination. (2009). Systematic Reviews: CRD's guidance for undertaking reviews in health care. University of York.

13. `Julian Higgins, Sally Green. (2011). Cochrane Handbook for Systematic Review of Interventions. The Cochrane Collaboration.

14. ^National Institute for Health and Clinical Excellence. (2009). Methods for the development of NICE public health guidance. 2 [edition]. National Institute for Health and Clinical Excellence.

15. `Xiaoli Huang, Jimmy Lin, Dina Demner-Fushman. (2006). Evaluation of PICO as a Knowledge Representation for Clinical Questions. AMIA Annual Symposium Proceedings.

16. ^National Institute for Health and Care Excellence. (2012). Quality appraisal checklist - quantitative intervention studies.

17. ^Critical Appraisal Skills Programme. (2018). CASP (Qualitative) Checklist.

18. a, b James Thomas, Angela Harden. (2008). Methods for the thematic synthesis of qualitative research in systematic reviews. BMC Medical Research Methodology, vol. 8 .

19. ^Karen Jacques, Paul J. Taylor. (2008). Male and female suicide bombers: different sexes, different reasons?. Studies in Conflict \& Terrorism, vol. 31 .

20. ${ }^{a, b}$ Revital Sela-Shayovitz. (2007). Suicide bombers in Israel: Their motivations, characteristics, and prior activity in terrorist organizations. International Journal of Conflict and Violence (IJCV), vol. 1.

21. a, b, c, dAngela Dalton, Victor Asal. (2011). Is it ideology or desperation: Why do organizations deploy women in violent terrorist attacks?. Studies in Conflict \& Terrorism, vol. 34 .

22. a, b, c Hamdi Muluk, Nathanael G. Sumaktoyo, Dhyah M. Ruth. (2013). Jihad as justification: National survey evidence of belief in violent jihad as a mediating factor for sacred violence among Muslims in Indonesia. Asian Journal of Social Psychology, vol. 16.

23. a, b Mirra N. Milla, Faturochman Faturochman, Djamaludin Ancok. (2013). The impact of leader-follower interactions on the radicalization of terrorists: A case study of the Bali bombers. Asian Journal of Social Psychology, vol. 16 .

24. a, b, c Walter R. Schumm, Charles V. Anderson, Angelia S. Brinneman, Mary E. Magsanoc-Deoki, et al. (2006).ReAnalysis of Sageman's (2004) and Pape's (2005) Data Predicting Al'Qaeda Membership and Suicide Terrorism. Psychol Rep, vol. 98 (3), 915-917. doi:10.2466/pr0.98.3.915-917.

25. a, b Sageman M. (2011). Understanding Terror Networks. Philadelphia: University of Pennsylvania Press.

26. ^Pape RA. (2005). Al Qaeda's Smart Bombs. New York Times. July 9.

27. a, b, c Jamie Bartlett, Carl Miller. (2012). The Edge of Violence: Towards Telling the Difference Between Violent and Non-Violent Radicalization. Terrorism and Political Violence, vol. 24 (1), 1-21. doi:10.1080/09546553.2011.594923.

28. `Bart Schuurman, John G. Horgan. (2016). Rationales for terrorist violence in homegrown jihadist groups: A case study from the Netherlands. Aggression and Violent Behavior, vol. 27 , 55-63. doi:10.1016/j.avb.2016.02.005. 
29. ${ }^{a}, \mathrm{~b}$ Anne Speckhard, Khapta Akhmedova. (2006). Black widows: The Chechen female suicide terrorists. Female suicide bombers: Dying for equality, vol. 84(1):63-80 .

30. a, bSHAUL KIMHI, SHEMUEL EVEN. (2004). Who Are the Palestinian Suicide Bombers?. Terrorism and Political Violence, vol. 16 (4), 815-840. doi:10.1080/095465590899740.

31. ${ }^{a}$, baumana Amjad, Alex M. Wood. (2009). Identifying and changing the normative beliefs about aggression which lead young Muslim adults to join extremist anti-Semitic groups in Pakistan. Aggr. Behav., vol. 35 (6), 514-519. doi:10.1002/ab.20325.

32. ^Hamm MS. (2009). Prison Islam in the age of sacred terror. The British Journal of Criminology., vol. 49(5):667-85. Jun 9.

33. ^Wills G. (2007). Head and Heart: a history of Christianity in America. New York: Penguin Books.

34. ^Newmann P. (2010). Prisons and Terrorism: radicalisation and de-radicalisation in 15 countries. London: International Centre for the Study of Radicalisation and Political Violence. (July).

35. ^Bryan F. Bubolz, Pete Simi. (2015). Leaving the World of Hate. American Behavioral Scientist, vol. 59 (12), 15881608. doi:10.1177/0002764215588814.

36. 'Balch RW. When the light goes out, darkness comes: A study of defection from a totalistic cult. In, Religious movements: Genesis, exodus, and numbers, R. Stark (ed.). New York, NY: Paragon House. 1986;11-63.

37. ^BBC News. (2019). Shamima Begum case. Accessed 05 Nov 2019.

38. ^BBC News. (2009). Islamic State: How could these children get home?. Accessed 05 Nov 2019.

39. ^ E. Kevin Kelloway. (1995). Structural equation modelling in perspective. J. Organiz. Behav., vol. 16 (3), 215-224. doi:10.1002/job.4030160304.

40. ^Hal Morgenstern. (1995). Ecologic Studies in Epidemiology: Concepts, Principles, and Methods. Annu. Rev. Public Health, vol. 16 (1), 61-81. doi:10.1146/annurev.pu.16.050195.000425.

41. 'Ziasma Haneef Khan, P. J. Watson, Zhuo Chen. (2016). Muslim Spirituality, Religious Coping, and Reactions to Terrorism Among Pakistani University Students. J Relig Health, vol. 55 (6), 2086-2098. doi:10.1007/s10943-016-02632. 